\title{
The Formative Values of 9-Year School Pupils in the subject "My Birthplace" (Fieri Schools Case)
}

\author{
Jani Sota Ph.D \\ "Aleksandër Moisiu" University of Durrës \\ E-mail:jani_sota@yahoo.com
}

Doi:10.5901/ajis/2013.v2n1p341

\begin{abstract}
In the entire operation of the school, the civic education of students occupies an important place, where the primary role for its realization is played by the history and geography of their birthplace, which together, via a broad activity, in and out the educational process, showing students concepts for the geographical area of the location of their birthplace; understanding of how geographic space is used in the service of human society; the connections and differences report of natural elements with the social community; for the relations in today's society, they show the long path of humanity, its history, its ceaseless struggle for development and progress; education and motivation and the feeling of love for their birthplace, etc.. Why should they recognize their birthplace? Firstly, all the cognitive activity of the child starts from the nearest to the farthermost. It starst with known and broadens its perspective to the mysteries of the universe. Secondly, recognizing the historic values of their own country, of their ancestors, they take great pride in and are enticed to do something, that their country and their city develop increasingly as the other European nations; and thirdly, recognizing their birthplace they are most likely to build their future life, to choose their path in life, you get used to exploit different sources and put them in the development of family service, of the community and of the entire society, etc.
\end{abstract}

Key words: History, geographical environment, industry, agriculture, culture, Fier.

\section{Introduction}

In addition to the continuous work in the years of improving the quality of teaching, supporting social and economic development of the country, in accordance with the requirements of the market economy, there are presented long-term objectives to the Albanian society from the Ministry of Education and Science (MES).

To achieve these objectives there has been a parallel movement to reform and improve the education system and curriculum. On the other hand, best efforts are made to improving the school infrastructure. All these lead naturally in enhancement of quality teaching and educational modernization.

For a long time professionals have been working on the new $5+4+3$ education. For this new curricula are designed, new textbooks with quality without excessive loads, in accordance with the country's economic directions. They aim to "ensure coherence and scientific level of a particular discipline." Through Native Program students can develop skills, values and attitudes that will influence their decisions and actions now and in the future.

Regarding Native Program, it should include spiritual and moral dimension, must develop and implement it should be described by culture and patriotic spirit. An important aspect of this process is the drafting of the text "My Hometown Fier" for fifth grade. Particularities are based on program for 
the birthplace, while the text has undergone radical changes in content and form of conception, giving the opportunity for a dignified presentation of the texts, images and color photographs and specific resource materials as well as the contemporary standard methods used in the classroom."

This creates the possibility of free competition, not only for native program texts but also for the work of teachers and especially students.

\section{The role of native teachers in Fier schools}

The fact is that originally native birthplace has not had a specific text as it was impossible for municipalities, and in addition to specific villages, to prepare materials needed for class. In conversations with the teachers of this subject, despite the passion and commitment to working with students to conclude that they had a primary duty of collecting, gathering, processing and treatment of topics in the environment where the school is located on a model scale according to region. In this context, they collaborated with historians, geographers, sociologists, archaeologists, with the most experienced teachers and other intellectuals of Fier community, local government administration, businessmen, and immigrants and why not with their students.

Thus, teachers through group work, managed to pile necessary information, to refine and adapt according to age-appropriate school grade.

From the data collected in official way, in all schools of Fier, the subject of geography and history it is generally provided by the respective profile of teachers. But it also lacks specific cases, especially in rural areas where there are shortages of teachers of geography and history with appropriate education. However, the primary task for teachers is generally continuous self study training in the field of geography and history but also in other areas of study.

With great interest were the qualifying activities for teachers that taught Native Program subject based according to schools, areas or district level. But it is important that all relevant qualifying activities are targeted to educational administrators or native teachers:

- Develop and enhance the knowledge and skills to understand the development of geography and history, social contexts of education, principles of native geography curriculum;

- Be able to prepare a lesson, a module of a course and a program previously given for the native area to involve students in gathering information from nearby sources and the media;

- Have skill and ability to use native potential as an educational tool for personal development, to ensure the equality of the right to have all students for effective local geographical knowledge.

\section{Some innovation to the Native Program reflected in the text of "My Hometown Fier"}

As a teacher and lecturer, textbook author and work booklet "My Hometown Fier", referring to the curricular structure approved by the Ministry of Education and Science (MES), we can say that the subject matter of the native program in all five classes took place from 2 hours a week. In 70 hours (35 weeks $x 2$ hours), it should be noted that 34 hours occupied new knowledge, combining knowledge of geography, history and social education; language, literature and knowledge of nature; visual education, music and physical ; on population, economy, education, sport, tourism, etc..

About the program, I thought that the program carefully crafted new feeds with clear demands of scientific objectives, methodology, practical implementation, integration and especially technical ones. Thus, in first place can create the impression of a busy program but in the textbook form it is clear that knowledge comes gradually more attractive for students. This escalation of knowledge aims to give not 
only the information necessary for the hometown but also "serve to promote more logical and creative thinking of students."

In this context practical work hours ( 24 hours) also serve for important topics at home. In these classes the student is back at the center of work in the classroom and outside, being driven to give his contribution in teaching each topic. This helps them to work independently, to better apply theoretical knowledge obtained in classes.

The class presentation and four basic colors figures, as well as other important elements, play a key role in the assimilation of rapid, accurate and meaningful new knowledge should be accomplished in about 87 pages.

There were some reasons to undertake the drafting of the text. The long experience in graduate and undergraduate education, the pursuit of children and the difficulties that faced them in the case of 9-year-old native program, the lack of a text drafted by specialists forcing them to take teaching topics by notes (handwritten), had made these difficulties to be most vulnerable.

The novelty of this program forced me to cooperate with renowned teacher researchers in the field of geography, history, archeology and other intellectuals of the community, local government administration, businessmen, immigrants and students, trying to made this text. However, while we are open to any feedback from teachers, students and their parents or from other readers who have in hand the text "My Hometown Fier".

The program is divided with specific topics, beginning with the physical-geographical data of the birthplace; continues with natural resources (assets and underground water, forests, mild climate, living world, natural beauty, etc..) and human resources (population since antiquity, lifestyles, traditions of the people, their characteristic features such as: brave, patriotic, hospitable, cultured, love for education, etc.., lifestyle, material and spiritual wealth, urban or rural settlements, the organization of life in the past until today, etc..); regional economy (agriculture and livestock development, industry, transport, tourism, sports, etc..);-society relations and the environment in recent threads, the story of the territory (historical events, biographies of national figures and those people who are examples of human experience) and educational, cultural, health of past sports.

What has changed in presenting scientific material in this text and how was it conceived? What is the structure of the text, although this structure does not change at all topics in the form? These are questions that arise naturally.

Presenting scientific material according to support structure adopted by MES, the program is divided into several sections. Thus, students are presented with short and clear theoretical and practical work, additional reading columns or questions and theoretical or practical tasks after teaching in the classroom or at home.

It should be noted that sections always begin with the theoretical material associated with the practical tasks of the notebook of the work, sustain, first, the concepts of space geographic location of the territory, on the particulars of the nature of it, population, economy and history of events. The most important of the past up to the present day is the diversity of cultural heritage. They create opportunities for teachers in classroom to organize and apply modern methods of teaching and learning with the students and also give students space to create and apply. Various applications start from aesthetic aspect to text or photo albums and the school museum.

What we tried to achieve together with the choices in this text? Based on the experience of teachers in the district of Fier and pedagogical opinion of specialists in the field of education, especially the 9year-system, the underlying text "My Hometown Fier" is the relationship of theory and practice, enabling recognition of deep explorations made in the area of Myzeqe. Besides the chosen ones, in this article we have tried to achieve:

I. Scientific vocabulary and language to be clear, that "the book speaks your language." 
2. Content of the text and notebook exercises are in accordance with the closely related to the major developments of social sciences that currently have completely changed their formative core facility being considered more and more as cognitive studies, applied and critical human studies of the environment in which we live.

3. Efforts for not having parallels with other social subjects but be integrated with them with the same symbolism in all educational topics.

4. Placing a lot of work practice achievable by all students, understandable for their age, possible in terms of any school in the city or in the villages and moreover non-intrusive for the teacher. This makes the book interesting and acceptable to all 9-year-system schools.

5. Links to theory, practical work in the classroom or at home, additional readings, assignments for each lesson topic, excursions, etc.., making students to follow a rhythm in obtaining information in such a way that it is not in a monotonous pace. Such monotony is broken with different activities that can take place inside or outside the school. These are not simply the desire of teachers as they have been so far but tasks are given in the text to be completed. Such competitions, working with a collection of photographic and archaeological materials, presentations or photo albums works constructed by the students themselves, meeting with veterans of war and labor or personalities who have left their mark in the memory of the community, the organization of excursions near the historical and ancient sites etc.., that age itself is curious enough to create opportunities for the native program to become a subject dear to all without exception.

6. This presentation of knowledge makes it possible for the parents to be closer to their children because for them it is not difficult. In this context, this is a new innovation in this regard.

7. The uniqueness of this text is the introduction of scientific and informative material related to civic education, which deals with environmental issues in the district of Fier and beyond. Thus, when students are introduced to environmental problems, they are given the task in the text for the development of scientific debates or creating scientific essays, taken incentive by two photos, a green environment with flowers and another of a polluted environment of dumped waste or from car fumes. Here, there is space for teachers in organizing class, both for students and create space for the recognition of the legislation and its implementation.

8. When the text deals with historical values and environmental, archaeological, ethnographic, architectural, artistic and cultural activities, the student recognizes not only the cultural and natural heritage values but also with the Albanian and international part of which is to protect monuments of natural and cultural values.

All work carried out has been in regard to the implementation of the program adopted by MES; modern teaching methods based for student and teacher in the role of a mastermind class; assessment of writing students with theoretical knowledge tests; students can gain practical skills and different applications. Similarly, the presentation of these works and the theoretical and practical interpretation is made evident in the practical skills, the development of scientific debate, as the tasks given in the text, like role-play, which can be done by using life personalities of the Albanian pantheon given in separate columns in the text, participation in learning, applying knowledge in new theoretical and practical situations.

All of these play an important role in shaping citizen students, "a free democratic society to develop independent, critical, capable of living together with their environment and at the same time to change it creatively looking to the future.

On the other hand, based on psycho-educational pedagogy, it is known that different types of students are present in class, therefore, this text provides an opportunity for all students to express 
themselves in their own way and the teacher identifies and assesses the skills acquired by the student on practical and theoretical level.

What is required from teachers according to the text is to work hard on student's communication skills; use advanced teaching methods, change methods of evaluation only for theoretical knowledge and train them for scientific essays. Furthermore, in this text the student at the end of the school year will be clear about what they have learned. This is explained by the fact that in addition to the numerous sections, there is also an aesthetic appearance. Respective personalities for all occurrences or events are presented, as well as physical and geographical maps, administrative, historical, etc.., so that students are not tired to visualize what place occupied in the territory phenomena or historical events, geographical space or concepts learned.

\section{By this text you learn that:}

- The student is the subject of teaching and learning;

- Teacher must use contemporary teaching method;

- The parent is able to orient and control the child regardless of the type of education he/she has.

This presentation of scientific and methodical material pushes further to develop a different change, creating new spaces for students in the assimilation of new knowledge and applying them to life. In trying to help teachers who have chosen this text we present a curriculum guide for them:

\section{Notebook "My Hometown Fier", a practical guide for students}

To the range of textbooks is added another book with scientific educational value, Notebook "My Hometown Fier" for fifth grade. By this notebook we have tried to boost creative thinking and the desire to seek and disclose better knowledge that students have about their home country.

In it are combined questions in support of the text "My Hometown Fieri", which contains knowledge of geography, history and social education; Albanian language, literature and knowledge of nature; visual education, music and physical geogrpahy; knowledge about the population, economy, education, health, sports and tourism. The acquisition of this knowledge through the book and implementation through the notebook is a first step towards the promotion and development of the students' independent work.

We can rightly say that the Notebook is a guide to the workshops and excursions that will take place in the context of educational development. Structuring them as learning topics, allows teachers to implement practical work in lessons and for excursions up to 5 hours each according to the program approved by the MES. This assignment allows students to exercise in practical work and use a variety of teaching tools, such as: map (physical and political), dumb map, atlases, albums, charts, educational films, videos, statistics, camera, barometer for measuring temperature, objects of family legacy, old maps etc.. Also in the implementation of EC regulation in their practical work, teachers should use a variety of modern methods, such as: explanation, demonstration, discovery learning, discussion, debate, group work, drawings, projects, essays, contests, excursions associated with practical activities etc.

The subject's integration, the use of working papers, student research in community resources and professional culture dominate the object of native teachers, who work through it and the notebook text of "My Hometown Fier," is oriented towards a rich effective teaching. Moreover, their use will make it possible to promote logical thinking and creative students. 


\section{Native program interaction with other sciences}

Geography and history are central and independent subjects. They are a bridge between the natural sciences and social sciences. The problems of geography and history in the textbook are linked to other disciplines, such as: geology, biology, archeology, sociology, political science and economics, etc.

Lessons of native program we think have become more interesting and attractive to students, especially when they are combined with interesting lesson topics developed with geographical, historical, cultural data, etc., coupled with graphical maps, diagrams and by judging and giving environmental development alternatives according to human interest.

Also, very interesting was the dynamic development of the native program class when students were in practice class, when they thought and conceived about the region integrated with native program explanations on national, continental and global level, so when they go out with the wish to integrate their country in the big European family.

\section{Conclusion}

All subjects, some more, some less, have the potential to educate students with love and pride for their nation but social subjects have a larger space in this direction.

The subject of the native program lies in seats where almost every class teacher affects students' patriotic education. "My hometown Fier" is a discipline with significant national features. It relates to the study of the basic conditions of existence of societies in general and of the Albanian nation, especially the land where lives and works in the Fier community within and outside the region or neighborhood, as well as the development of the productive labor, their distribution and economy in its particular branches.

Ways to implement patriotic education are numerous. In all this activity, along with the text program, the role of the teacher is very important.

In all its activities, the teacher in charge through the object of native program should show to students multiple values of Fier territory and student, as sons and daughters of the people living there will be able to give their contribution in limiting inequalities of spatial development of cities in the distribution and welfare of the population, in order to increase confidence for exceptional skills and creative powers of human beings; becoming active members of society to maintain ecological values, to preserve the balance of natural interaction during human activity.

Therefore schools of Fier were targeted step by step and learning about topics created the conviction to students that our fathers left us our homeland and work it that we can leave it more beautiful and richer for generations to come.

\section{Literature}

Gjovalin Alia, "Aspects of the geography of the native (Puke school experience)", in: Curriculum and School History and Geography, Institute of Pedagogical Studies, no. 4, Tirana, 2003, p. I37.

IKS, Integrated curriculum ideas, challenges, suggestions, Tirana, 2007.

IKS, Students Assessment: A Teacher's Manual, Tirana, 2009.

IKS, Interactive teaching methods, Tirana, 2007.

ISP, School Curriculum (History and Geography), no. 4, Tirana, 2003.

ISP, Pedagogical magazine, no. 4, Tirana, 2007.

Kola, Bedri. "Module program" Homeland "(" local environment "): school-based curriculum ..., p. I38-I47.

Mato, Erleta. Gjedia, Robert, Dautaj, Astrit. (2006). 9-year education curriculum - social sciences (Civic Education, History, Geography), New York: "Kristalian-KH". 
Mehmeti, Ndriçim. "The program for home education curriculum and innovation for 9-year-grade school", in: school-based curriculum ..., f. II3.

Merita, Spahiu, Yllka. "The central curriculum development and school-based curricula in different educational systems", in: school-based curriculum - Modular Curriculum (hereinafter: School-based curriculum ...), curriculum and Standards Institute, Tirana, 2007, p. I0.

Sota, Jani. (20I I). My Hometown Fier - fifth grades 9-year-grade school, New York: "Erik".

Sota, Jani. (2012). Working notebook - My Hometown Fier (fifth grades), New York: "Erik".

Ziu, Trifon. (1999). Teaching of human geography, Tirana.

Xhelili, Qazim, (200I) Teaching History, New York: SHBL. 
